\title{
Chelation and ozone combination: the knock-out blow in treating IHD
}

\author{
Lenny Da Costa, MD
}

President of Society for Regenerative Aesthetic and Anti Aging Medicine, India.

\section{ABSTRACT}

\section{OPEN ACCESS}

\section{Citation}

Da Costa L. Chelation and ozone combination: the knockout blow in treating IHD [abstract]. Proceedings of the 5Th WFOT Meeting; 2016 Nov 18-20; Mumbai, India. J Ozone Ther. 2018;2(2). doi: 10.7203/ jo3t.2.2.2018.11161

\section{Academic Editor}

Jose Baeza-Noci, School of Medicine, Valencia University, SPAIN

\section{Editor}

World Federation of Ozone Therapy, Bolgna, ITALY

\section{Received}

December 9, 2017

\section{Accepted}

December 10, 2017

Published

March 4, 2018

\section{Intellectual Property}

Lenny $\mathrm{Da}$ Costa. This is an open access article distributed under the terms of the Creative Commons Attribution License (CC BY 4.0), which permits unrestricted use, distribution, and reproduction in any medium, provided the original author and source are credited.

\section{ABSTRACT}

The recent TACT study published in the Journal of the American Medical Association showed that up to $50 \%$ of selected patients with heart disease will die from their disease unless they are treated with EDTA chelation therapy. Special benefits are seen in the diabetic population. TACT 2 is now underway to better understand the mechanisms at play to bring about this outcome. (Lamas, G. A., Goertz, C., Boineau, R., Mark, D. B., Rozema, T., Nahin, R. L., et al. (2013). Effect of disodium EDTA chelation regimen on cardiovascular events in patients with previous myocardial infarction: the TACT randomized trial. JAMA, 309(12), 1241-1250.)

Now a new study is offering proof that not only can EDTA chelation therapy treat heart disease, it can also treat the atherosclerosis that leads to heart disease.

The researchers looked at the effect of EDTA chelation therapy on 118 men and women with atherosclerosis. Their ages ranged from 48 to 89 years old. Before the study began, they measured the pulse wave velocity of their arteries. After only 10 chelation treatments, the pulse wave velocity readings decreased substantially. The arteries were becoming more flexible and less stiff. After 20 chelation treatments, the readings decreased even more. And after 30 treatments, the decrease in the readings seems to have reached their maximum in most of the patients. This is exactly what I have been seeing in my patients for the past 35 years. Maximum effect of chelation therapy tends to occur between 20-30 treatments (Tadashi Mitsuo, MD, Sigenori Nakano, MD, Masao Yoshida,MD, Hideki Ohno,MD, Kazuo Tsubota,MD. Na2EDTA Chelation Therapy Can Decrease baPWV in Elderly Patients. www.acam.org/news. Friday, June 13, 2014 )

When it comes to heart disease, the combination of Chelation and Ozone works even better than the chelation treatments by themselves. The chelation therapy treats the atherosclerosis and the ozone improves the way the heart cells use oxygen - a perfect marriage.

\section{Ozone therapy improves oxygen delivery and circulation by:}

1. Decreasing the viscosity and thickness of the blood, so that it can navigate the small capillaries better, and is easier to pump

2. Improves the ability of red blood cells to unload oxygen to the tissues. This persists long after the course of treatments is completed

3. Decreases inappropriate inflammation in the blood, allowing for the formation of nitric oxide to help the arteries dilate, further improving blood flow 
Author Information

drlennydacosta@gmail.com

\section{Chelation therapy improves circulation by:}

1. Removing heavy metals such as lead, which impair the formation of nitric oxide. Nitric oxide is produced by the lining of the blood vessels as a signal to help arteries relax and dilate, improving circulation

2. Delivering high doses of nutrients such as magnesium, acting as a natural calcium channel blocker to keep arteries dilated and relaxed 